\title{
Value Chain Analysis in Small Business Context
}

\author{
Mega Iskanti Putri, Budi Harsanto \\ Faculty of Economics and Business \\ Universitas Padjadjaran \\ Bandung, Indonesia \\ mega_iskanti@yahoo.com
}

\begin{abstract}
Value chain analysis is a tool to understand the activities that create value to company's product. Value chain analysis help companies in identifying the position of the company and analyze the activities in the value chain as well as eliminate activities that do not create added value to the product or service. The purpose of this paper to identify the activities in the value chain and to explore the problems in small business context. We used an interview and observation for data collection. As a case study, we elaborated a small firm in Bandung, Indonesia engaged in Muslim fashion industry. The result show that there are still many problems in the value chain in this company, ranging from primary activities to support activities. This paper is unique since its combine strategic and operations perspectives. Also there is still rare value chain analysis study in the context of small business, especially in emerging economies as Indonesia.
\end{abstract}

Keywords: value chain analysis, small business, operations management.

\section{INTRODUCTION}

Since ancient times, clothing has become a commodity business or commonly known by the fashion industry. The fashion industry has developed very quickly in the spread of its influence on people's life. This condition was in line with the growing public awareness of the fashion that has led to the fulfillment of the life style in dress, so it can be said that the need to dress in contemporary times is not only to cover the body, but also as a means of communication that can demonstrate the lifestyle and identity of the wearer.

Fashion industry is one of the potential of creative industries in Indonesia. Fashion product is one of the largest export contributors of creative industries. In August 2015, Minister of industry, Saleh Husin, said that from the 15 subsectors of the developed creative economy, there are three subsectors which provide the dominant contribution to GDP, namely, a culinary sector which reach Rp209 trillion, or 32.5 percent, fashion sectors reach Rp182 trillion or 28.3 percent, and the last one is craft sector that reach Rp93 trillion, or 14.4 percent. A deeper look at the export performance of the fashion industry, fashion industry exports reached Rp76,7 trillion, increase 8 percent compared to 2012. In addition to increased state revenues, the industry also has a positive value because it can absorb the workforce and the provision of national business field.
The fashion industry dominates the creative industries sector amounted to 54.32 percent with employment of 4.13 million people, or 4.22 percent of employment participation rate nationwide. The fashion industry is now growing in Indonesia in general and Bandung in particular. Ranging from clothing adults, adolescents, children, until the moslem clothing constantly evolving, along with the development of fashion. One of the clothing that is rising until today are moslem clothing or we can call it as fashion hijab. Indonesia as a qibla for moslem fashion hijab has made the fashion hijab is growing rapidly in the other parts of the world, and fashion hijab began to be recognized by the world's leading designers, such as Dolce \& Gabbana are now issuing their abaya collection.

One of analytical tool that can be used to provide information to make strategic decisions of companies is the value chain analysis. Value chain analysis is the full range of activities — including design, production, marketing and distribution - businesses go through to bring a product or service from conception to delivery. Value chain analysis is useful for aligning strategic and operations aspects in a company (1). For companies that produce goods, the value chain starts with the raw materials used to make their products, and consists of everything that is added to it before it is sold to consumers. MDFB as the object of this study is one of the hijab fashion brand which first appeared in the city of Bandung, where manufacturers focusing on casual wear products for use in everyday by the muslim woman, ranging from shirts, pants, hoods up. A company established in 2011 it now has stores in several cities as Bandung, Banjarmasin, Makassar, Surabaya, and Tangerang and in the near future will be setting up shop in Malang and Balikpapan. MDFB is a company that is well developed. We can see it from their branches which grow more and more as time goes on, and also can be seen from the sales data of the last 3 years respectively: Rp 367,764,000 (2013), Rp 452,109,000 (2014) and Rp 619,275,000 (2015).

The primary research used some of factors in the value chain. Those are support activities and primary activities. Support activities include several activities such as firm infrastructure (which includes accounting, finance, and strategic planning), human resource management (which regulates the recruiting, training, and development), technology development (which also includes $\mathrm{R} \& \mathrm{D}$, product and process development), and the last one is a procurement (which includes the purchasing of raw materials, machines, and suppliers). Dopico, Porral (2011) analyzes value chain in international fashion markets and find that the company need to have better control of operations (2). As for the primary 
activities include five activities, namely inbound logistics (which regulates raw materials handling, and warehousing), operations (which also includes machining, assembling, and testing products), outbound logistics (which includes dealing with warehousing, and distribution of finished goods), marketing and sales (which includes about advertising, promoting, pricing, and channel relations), and the latter is a service (which includes installation, and repair parts). Based on the description of the background, the objectives of this paper are to identify the activities in the value chain and to explore the problems in small business context.

\section{LITERATURE REVIEW}

\section{A. Operations Management}

An organization must be able to carry out four functions, they are marketing, operations, human resources and finance to produce goods and services. Operations management is one of the functions above that are directly related to other business functions. Operation Management is the set of activity that create value in the form of goods and services by transforming inputs into outputs. Activities creating goods and services take place in all organizations (3). This is the most widely known for the definition of operations management.

In the other definition, operations management is concerned with the design, implementation, and maintenance of the operations function in manufacturing and service organizations - the activity that is responsible for acquiring such resources as materials, technology, and skilled employees, and configuring processes to create and distribute goods and service to consumers (4). Similar with previous definition of operations management, operations management is the management of processes used to design, supply, produce, and deliver valuable goods and services to customers (5). And the last definition said that operations management is the science and art of ensuring that goods and services are created and delivered successfully to customers (6).

Based on the explanation above, it can be concluded that the operations management is an organizational function that is responsible for the delivery of the added value of goods or services to consumers successfully through the process of transforming inputs into outputs.

\section{B. Supply Chain Management}

Supply Chain Management involving companies in supplying raw materials, produce goods, and sends it to the final consumer. Supply chain management is not only oriented to internal affairs, but external affairs concerning the company's relationships with other companies. Supply chain management is defined as all the activities involved in delivering a product from raw material through the customer including sourcing raw material and parts, manufacturing and assembly, warehousing and inventory tracking, order entry and order management, distribution across all channels, delivery to the customer, and the information system necessary to monitor all of the activities (7).

Similar with the previous definition, Supply Chain Management consists of all parties involved, directly or indirectly, in fulfilling a customer request. The supply chain includes not only the manufacturer and suppliers, but also transporters, warehouses, retailers, and even customers themselves. Within each organization, such as manufacturer, the supply chain includes all functions involved in receiving and filling a customer request. These functions include, but are not limited to, new product development, marketing, operations, distributions, finance, and customer service. In the other definition, supply chain management is a strategic coordination of the supply chain with the aim of integrating the management of supply and demand.

Last but not least, supply chain management is a management activity in order to acquire the raw materials into semi-finished goods and finished goods then send the product to consumers through the distribution system. These activities cover the traditional purchasing function plus other important activities related between suppliers and distributors (3). Based on the explanation above we can conclude that supply chain management are all activities related to the flow of material, information and money along the supply chain. Specifically, supply chain management includes all the following things.

\section{Value Chain Analysis}

Value chain analysis is a useful analytical tool for understanding the activities that make up the value of a product or service and is used to create value for its customers in achieving a competitive advantage. Objective value-chain analysis is to identify the stages of the value chain where the firm can increase value for the customer or for lower costs. Cost reduction or increase in value added to make the company more competitive. Value chain analysis helps the company identify and analyze the company's position that there are activities in the value chain as well as reduce or eliminate activities that do not create added value to the product or service.

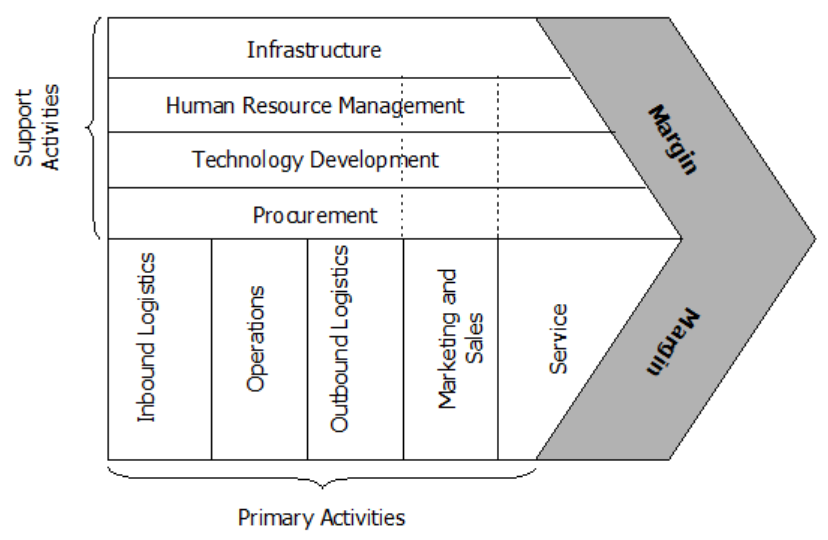

Porter 1985

Figure 1. Value Chain Porter

Value chain analysis is analyzing the activities of collection activities undertaken to design, produce, market, deliver and support products or services. Another definition said value chain analysis describes a way to look at the company as a chain of activities that transform inputs into outputs that value to the customer. Other definition said value chain analysis is a technique widely applied in the fields of operations 
management, process engineering and supply chain management, for the analysis and subsequent improvement of resources utilization and product flow within manufacturing processes (8). The use of value chain scattered in various field (9). Based on the explanation above, we can conclude that value chain analysis is an analytical tool strategies used to gain a better understanding of the competitive advantages, to identify where the value of customers can be increased or decreased costs, and to understand better of the company's relationships with suppliers, customers and other companies in the industry. Value Chain identify and connect various strategic activities in the company.

\section{METHOD}

According to I Made Wirartha (2006: 68) research method is a branch of science that discuss or question the ways of carrying out research (that includes searching, recording, formulate, analyze to draw up a report) is based on facts or phenomena scientifically (10). By using the method of research, can be found a significant relationship between the variables studied and the conclusions that will clarify the picture of the object under study. And the method I use is the qualitative descriptive method. Qualitative method with descriptive approach used in this study, is a qualitative method to obtain in-depth data, a data implies. Qualitative methods can significantly affect the substance of the study. It means that the present method of direct qualitative nature of the relationship between researchers and informants, object and subject of research.

One of the method of qualitative descriptive study is the case study method. This study focuses intensively on a single object that is studied as a case. The case study data can be obtained from all parties concerned, in other words, this case study data collected from various sources. Case study is a method for investigating or studying an event in depth against an individual, institution, or any other subject. The main objective of qualitative research is to understand the phenomenon or a social phenomenon with more focused on the complete picture of the phenomenon under study rather than develop them into variables are interrelated. The outlook is acquired a deep understanding of the phenomenon to further produced a theory. Because the goal is different from quantitative research, the data acquisition procedures also different between qualitative and quantitative research.

Data used in this research is a primary and secondary data. Primary data is data obtained directly in the field by researchers as the object of writing. Depth interviews or indepth interviews were used to obtain the data by the method of interviews with sources who will be interviewed. Secondary data is data that is obtained indirectly or through an intermediary medium (obtained and recorded by others) as well as data obtained and compiled by researchers from various existing sources. This data was also obtained from books, journals, previous studies, and articles related to this research.

\section{RESULTS AND DISCUSSION}

This section will explain the value chain analysis of MDFB, which consist of primary activities and support activities.

\section{A. Primary Activities}

\section{1) Inbound Logistics}

Lateness in delivery time rarely happens in MDFB, because the main vendor (fabric) of the materials is close by the company. They are in the same area which is in Arcamanik, when MDFB needs the materials, they can send it right away because the distance between the store and the vendor is close enough.

MDFB has storage for raw materials, but what happens in the field is the raw material stacked outside, and in fact, they just mixed all the fabrics that will be produced for different months, which takes longer to the production process. Raw materials piled up because they have the storage for store the fabric, but the goods are too much that cannot fit in the storage, because the owner of MDFB, when having cash is buying the fabric all over again. Without visible benefits and usefulness, because sometimes, after they bought the materials and it turns out a little, they do not use those materials and it just leads to wasting money.

In the other hand, the problem faced by MDFB is their distribution of material. First, because the location of the company is in a residential area, which is not proper for a manufacturing company because it can interfere with the surroundings environment, make the company should have a spread vendor (beside fabric). By having a spread vendor, it leads the company to pay a higher cost for the delivery of raw materials or even finished goods.

\section{2) Operations}

At the company's MDFB there are several issues that are found on some parts of the operations. Starting from the location, layout, inventory and scheduling.

-Location: MDFB office is located at Arcamanik Bandung, actually it's not an office, but the house of the owner of MDFB, they make the office and the house together as one, which means this office is actually located in a residential area. With the existing production process in house, from inbound logistics, manufacturing of clothes design, sample making, quality control, and more make this location less suitable for the office, because it can disturb surrounding residents. Last year, all production processes are in this house, ranging from sewers totaling tens work in one place. However, after protests from local residents made them finally decide specifically to sample only who works in the house.

-Layout: What happened in this MDFB is, starting from the absence of an organizational structure that will certainly affect the layout of the workers. In the absence of organizational structure, the workers do not know if this problem should be reported to anyone, all just focused on one person. Moreover, what happens is unclear material flow, starting from where the goods came to be stored, to the process ends where and where. Each new material comes just stacked in the same place. 
-Inventory: Inventory for raw materials in MDFB is not in a proper one, because the employees just piled up everything and mix it into one. Below is the real condition in the company. In the other hand, lack of inventory for finished goods is also happened, because they pile the finished goods outside the warehouse they already provide, because sometimes the finished goods came in the afternoon, and the person who is responsible of warehouse already go back home, because they need to input the data of the goods before going in to the warehouse, and by that, the other workers just piled up everything outside.

- Scheduling: They need a long process starting from design to finished goods. However, MDFB does not have a good scheduling system, because they are still a family business, so to scheduling did as they pleased. For the newest collection, design clothes should be able to take only four days, it could take longer than that. Because of its performance really depend only on one person. When early in the process already too late, it will continue until the end. The delay problems affect to the sale system which is a pre-order system and also affect to consumer's trust.

\section{3) Outbound Logistics}

In MDFB, outbound logistics occurring form is the distribution of finished products to the branches and resellers spread in different cities, and resellers who are abroad. This distribution is usually done by the air rather than by the sea. If we see from the delivery time, there is no question that air freight is usually much faster. Many sea shipments can take around a month to arrive while an air shipment takes a day or two. For most business shipping, faster is better. But it should be noted that technology keeps moving forward in the international shipping world, ships are getting faster, canal have created shorter shipping routes. There are many ocean freight shipments crossing the oceans and being delivered in as few as 8 days.

If we see from the delivery cost, typically shipping by ocean is cheaper that shipping by air, but sometimes warehousing fees at the seaports are many times more expensive instead of the airports. In MDFB, before they send all the products to another city or abroad, they used to double check the product. For the damage level, MDFB is in the low level, because on their production process, they already have quality control in 2 process, in sample and in finished goods. It is really rare to find the damage product in MDFB.

\section{4) Marketing and Sales}

MDFB does both on marketing and sales. They do the promotion more in online basis, even for offline promotion, they promote it by online first. Nowadays, people tend to attract more to buy online rather than to go to the shop. In the other way of marketing, MDFB offers cooperation in the form of licensing. Other people can use MDFB's name and sell the products. But, because this business is a family business, the system they use is still not too strict. Sometimes they are overwhelmed by this licensing partnership. MDFB provides discounts up to $40 \%$, however, MDFB still handle everything well, from their sales per day, shopping bags, promotional forms, sale products, and even MDFB still take care of products that hard to sell. Whereas with a discount that is large enough, this license cooperation should no longer need to bother MDFB with their small things.

\section{5) Service}

The service of this company so far is not experiencing any problems, because when seen from the number of customers and sales, they continue to rise each year of going online and offline.

\section{B. Support Activities}

\section{1) Firm Infrastructure}

Problems were found in the company's MDFB on finance is, they do not have people working specifically to regulate corporate finance. Thus, among the household money and business money is still mixed into one. Also, when they have excess money, they always invest the money to the fabric, whether the fabric will be required later on or not, and it just led to wasting the business money. MDFB also does not have a general manager, first, because they do not have an organizational structure, job description and the job specification, and it makes the company does not know what kind of people needed and hired to run the company. Without having a complete structure in the company, makes the company does not have any kind of specific goals, target, or plan to achieve within a certain period.

\section{2) Human Resource Management}

As explained before about the organizational structure, it also has an impact to the human resource management, because the organizational structure directly related with people who works within the company. It affects to the employee's behavior, they tend to rely on each other, because when a problem appears, they do not know how to solve and who can solve the problem, and usually all the problems occur within the company handled only by the owner.

In addition, for the labor cost incurred by MDFB there are two systems. For workers who are down in the fields of technology, sales, shop, design, and others, they get a fixed monthly salary. However, for the labor, working in terms of cutting the fabric, making patterns, sewing, and others, they were paid according the products they produce, and paid every week. For MDFB itself is actually no clear career planning because it is still a small and medium enterprise, as well as a family enterprise. It might happen only for a raise salary, but there is no clear career path in this company.

\section{3) Technology}

In MDFB, they already have a good people working on the computer software development, equipment design, database, and the development of computer systems. They do not have any specific problem in technology.

\section{4) Procurement}

In manufacturing, the goods to be purchased by the procurement division can be generally classified into raw materials and components for production, capital equipment 


\section{Arinuris PRESS}

such as machinery and equipment Other long-term as well as machine and land. MDFB only rely on 1 vendor in the fabric procurement. What often happens is, they've been buying fabric and when they want to repeat order, the fabric is not available, and they do not have any other choice instead of buying another fabric. MDFB also less well in regulating procurement, because they can buy the raw materials only based on money they hold and the price of the fabric. While being cheap, MDFB buy materials with extraordinary amount without a clear plan whether the material will be used or not in the future. Every purchase of raw materials by MDFB, the payment system is directly and immediately pays in full. MDFB always buys raw materials when they are already holding cash in hand. So there is no debt to matters outside the raw materials.

\section{CONCLUSION}

One of analytical tool that can be used to provide information to make strategic decisions of companies is the value chain analysis. Value chain analysis is the full range of activities - including design, production, marketing and distribution - businesses go through to bring a product or service from conception to delivery. Based on analysis in MFDB company, there are still many room for improvements found on each of the sub-variables of the value chain itself. As in primary activities are divided into five activities, namely inbound logistics, operations, outbound logistics, marketing and sales, and service, from 5 of these activities, only in the service which is not experiencing any problems, the rest are having problems. As for support activities, of which there are four activities, namely firm infrastructure, human resource management, technology, and procurement, only technology that is not experiencing problems. Means it can be concluded that the company is still experiencing many problems in the value chain analysis.

\section{REFERENCES}

[1] Fearne A, Garcia Martinez M, Dent B. Dimensions of sustainable value chains: implications for value chain analysis. Supply Chain Manag An Int J [Internet]. Emerald Group Publishing Limited; 2012 Sep 21 [cited 2016 Aug 21];17(6):575-81. Available from: http://www.emeraldinsight.com/doi/abs/10.1108/13598541211269193

[2] Dopico DC, Porral CC. Analysis of value chain and sources of differentiation in international fashion markets. Eur Res Stud J. 2011;14(1):15-28.

[3] Heizer J, Render B. Operations Management (8th Edition). Prentice Hall; 2006.

[4] Evans IAS, James R. Principles of operations management. 2005;

[5] Cooper SM, Hartley. Cooper, and Hartley. 2011. Managing Operations Across the Supply Chain. 2011.

[6] Collier DA, Evans JR. OM4. South-Western Cengage Learning; 2013.

[7] Vokurka RJ, Zank GM, Lund CM. Improving Competitiveness Through Supply Chain Management: A Cumulative Improvement Approach. Compet Rev [Internet]. MCB UP Ltd; 2002 Jan [cited 2016 Aug 21];12(1):14-25. Available from: http://www.emeraldinsight.com/doi/abs/10.1108/eb046431

[8] Womack JP, Jones DT, Roos D. Machine that changed the world. Simon and Schuster; 1990.

[9] Keivan Zokaei A, Simons DW. Value chain analysis in consumer focus improvement: a case study of the UK red meat industry. Int J Logist Manag. Emerald Group Publishing Limited; 2006;17(2):141-62.

[10] Wirartha IM. Metodologi Penelitian Sosial Ekonomi. CV Andi Offset Yogyakarta. 2006. 